\title{
P01-004 - MEFV genes and FMF
}

\author{
F Salehzadeh ${ }^{1,2^{*}}$, M Jafariasl ${ }^{2}$, S Jahangiri ${ }^{1}$, S Hosseinias $\left.\right|^{3}$ \\ From 7th Congress of International Society of Systemic Auto-Inflammatory Diseases (ISSAID) \\ Lausanne, Switerland. 22-26 May 2013
}

\section{Introduction}

Familial Mediterranean Fever (FMF) is a hereditary autoinflammatory disease with autosomal recessive inheritance pattern often seen in the Turks, Arabs, Armenians and Jews people characterised by recurrent episoded of fever and polyserositis and rash. Recently the definitive diagnosis of FMF determines by MEFV gene analysis.

\section{Objectives}

In this study we analysed twelve MEFV gene mutations inmore than two hundred FMF patients who had Mediterranean fever diagnosis on the basis of clinical Tel Hashomer criteria.

\section{Methods}

In northwest of IRAN, 216 patients with FMF diagnosis based on Tel-Hashomer criteria, referred to the genetic laboratory to12 common MEFV genes analysis. P369S, F479L, M680I(G/C), M680I(G/A), I692del, M694V, M694I, K695R, V726A, A744S, R761H, E148Q mutations were analysed by using amplification refractory system for 11 of those and the PCR was performed for E148Q.

\section{Results}

Among Of these FMF patients, no mutation was detected in $51(23 / 62 \%)$ patients and $165(76 / 38 \%)$ patients had one or two mutation. 33 patients $(15 / 28 \%)$ homozygous, 86 patients $(39 / 81 \%)$ were compound heterozygous, 46 patients $(21 / 29 \%)$ were heterozygous. The most common mutation, were M694V (23/61\%) V726A (11/11\%) and E148Q (9/95\%) respectively.

\section{Conclusion}

Common 12 MEFV genes analysis could not detect $50 \%$ of our patient who had FMF on the basis of Tel - Hashomer clinical criteria. Therefore it needs more genes analysis in

'Pediatric Rheumatology, Bouali Hospital, Iran, Islamic Republic Of

Full list of author information is available at the end of the article genotyping studies, we conclude that clinical criteria is still the best way in diagnosis of FMF.

\section{Disclosure of interest}

None declared.

\section{Authors' details}

'Pediatric Rheumatology, Bouali Hospital, Iran, Islamic Republic Of. ${ }^{2}$ Pediatric Rheumatology, ARUMS, Iran, Islamic Republic Of. ${ }^{3}$ Genetic, Emam Khomeini hospital, Ardabil, Iran, Islamic Republic Of.

Published: 8 November 2013

doi:10.1186/1546-0096-11-S1-A8

Cite this article as: Salehzadeh et al:: P01-004 - MEFV genes and FMF. Pediatric Rheumatology 2013 11(Suppl 1):A8. and take full advantage of:

- Convenient online submission

- Thorough peer review

- No space constraints or color figure charges

- Immediate publication on acceptance

- Inclusion in PubMed, CAS, Scopus and Google Scholar

- Research which is freely available for redistribution 